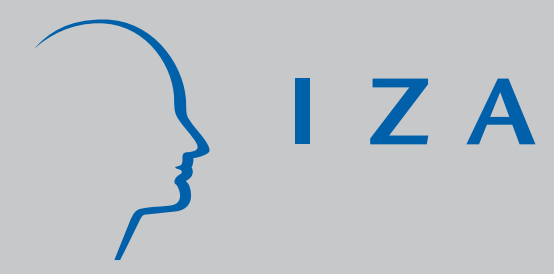

IZA DP No. 840

Equilibrium Unemployment Under Negotiated Profit Sharing

Erkki Koskela

Rune Stenbacka

August 2003 


\title{
Equilibrium Unemployment Under Negotiated Profit Sharing
}

\author{
Erkki Koskela \\ University of Helsinki, Bank of Finland \\ and IZA Bonn \\ Rune Stenbacka \\ Swedish School of Economics \\ Discussion Paper No. 840 \\ August 2003
}

\author{
IZA \\ P.O. Box 7240 \\ D-53072 Bonn \\ Germany \\ Tel.: +49-228-3894-0 \\ Fax: +49-228-3894-210 \\ Email: iza@iza.org
}

This Discussion Paper is issued within the framework of IZA's research area Mobility and Flexibility of Labor. Any opinions expressed here are those of the author(s) and not those of the institute. Research disseminated by IZA may include views on policy, but the institute itself takes no institutional policy positions.

The Institute for the Study of Labor (IZA) in Bonn is a local and virtual international research center and a place of communication between science, politics and business. IZA is an independent, nonprofit limited liability company (Gesellschaft mit beschränkter Haftung) supported by Deutsche Post World Net. The center is associated with the University of Bonn and offers a stimulating research environment through its research networks, research support, and visitors and doctoral programs. IZA engages in (i) original and internationally competitive research in all fields of labor economics, (ii) development of policy concepts, and (iii) dissemination of research results and concepts to the interested public. The current research program deals with (1) mobility and flexibility of labor, (2) internationalization of labor markets, (3) welfare state and labor market, (4) labor markets in transition countries, (5) the future of labor, (6) evaluation of labor market policies and projects and (7) general labor economics.

IZA Discussion Papers often represent preliminary work and are circulated to encourage discussion. Citation of such a paper should account for its provisional character. A revised version may be available on the IZA website (www.iza.org) or directly from the author. 
IZA Discussion Paper No. 840

August 2003

\section{ABSTRACT}

\section{Equilibrium Unemployment Under Negotiated Profit Sharing*}

We study employment, employee effort, wages and profit sharing when firms face stochastic revenue shocks and when base wages and profit shares are determined through negotiations. The negotiated profit share depends positively on the relative bargaining power of the trade union and it has effort-enhancing and wage-moderating effects. We show that higher profit sharing reduces equilibrium unemployment under circumstances with sufficiently 'rigid' labour market institutions, i.e. sufficiently high benefit-replacement ratios and relative bargaining powers of trade unions. Conversely, profit sharing seems to be destructive from the point of view of employment when the labour market 'rigidities' are sufficiently small.

JEL Classification: J51, J41, G32

Keywords: bargaining, profit sharing, efficiency wages, equilibrium unemployment

Corresponding author:

Erkki Koskela

Department of Economics

University of Helsinki

P.O. Box 54

00014 Helsinki

Finland

Email: erkki.koskela@helsinki.fi

\footnotetext{
* Koskela thanks the Research Unit of Economic Structures and Growth (University of Helsinki) and the Yrjö Jahnsson Foundation for financial support and the Bank of Finland for hospitality, whereas Stenbacka thanks the Yrjö Jahnsson Foundation for financial support. We also thank Toni Nordlund for research assistance.
} 


\section{Introduction}

Profit sharing refers to remuneration mechanisms with a performance-related scheme consisting of a base wage plus a share of profits or revenues of firms. Profit sharing is an empirically important phenomenon in many OECD countries. The OECD Employment Outlook (1995) reports cross-country evidence on the incidence of profit sharing in OECD countries. Pendleton et. al (2001) and the DICE database collected by CESifo (to be found on http://www.CESifo.de) present more recent data on the large proportion of workplaces with financial employee participation, in particular in the form of profit sharing schemes, in EU-countries. As profit sharing schemes are commonly used, it is important to study their implications for wage formation and equilibrium unemployment.

In a widespread book written for a broad audience Weitzman (1984) proposes profit sharing systems for economies facing unemployment and stagflation problems. In Weitzman (1985) and Weitzman (1986) the arguments are presented in a more rigorous way. In these articles Weitzman conjectures that profit sharing systems would dampen the business cycle fluctuations of employment and reduce equilibrium unemployment. Some key aspects of this intuition is formally developed by Holmlund (1991). He argues that the elasticity of substitution between labour and capital is a crucial determinant for the employment implications of profit sharing. More precisely, profit sharing will reduce (increase) equilibrium unemployment if and only if the elasticity of substitution between

labour and capital exceeds (falls short of) one, while it will have no effect on equilibrium unemployment when the elasticity of substitution between labour and capital is equal to one. Layard and Nickell (1990) show a similar neutrality result in the case of CobbDouglas production function and efficient bargaining. One important assumption in Holmlund's analysis is that the benefit-replacement ratio is proportional to the total compensation, including not only the base wage but also a component contingent on 
performance. In a model with capital stock decisions, Jerger and Michaelis (1999) develop this approach further and show how a switch from a fixed wage economy to a share economy may, in fact, decrease aggregate unemployment with the Cobb-Douglas production function when the outside option does not include the profit sharing. However, in all these contributions, which focus on a world with no uncertainty, the profit sharing instrument is assumed to have no incentive effect on effort decisions.

In the present analysis we highlight that also factors other the nature of the production technology are important for evaluations of the employment implications of profit sharing. We do this by focusing on a production technology with unit elasticity of substitution between labour and capital - the case where profit sharing would have no employment effect in light of Holmlund (1991), Layard and Nickell (1990) or Jerger and Michaelis (1999). We extend the analysis of this literature by incorporating efficiency wage effects in an environment with uncertainty. This way we are able to combine and unify elements from union bargaining and efficiency wage theories - approaches which have typically represented separate lines in the literature. Hence we can explore the implications of profit sharing in a more complete way.

Our analysis will offer a characterization of how the employment implications of profit sharing depend on the interplay between labour market policies and labour market imperfections. We will prove that profit sharing will stimulate employment under conditions with sufficiently high unemployment benefit replacement ratio and sufficiently strong labour market imperfections due to the bargaining power of trade unions. In line with the terminology used by, for example, Nickell (1997) we will refer to these circumstances as sufficiently strong labour market rigidities. With such labour market rigidities profit sharing will induce moderations of the base wages so as to boost aggregate employment. Conversely, we also show that profit sharing will have negative employment effects if labour market rigidities are sufficiently low.

We proceed as follows. Section II presents the basic structure of the model as well as the time sequence of decisions under circumstances where a firm operates in an environment characterized by uncertainty. The determination of effort by employees and the employment decisions by firms are studied in section III. In section IV we investigate the wage and profit sharing determination through negotiations in the presence of 
efficiency wage considerations. Section V explores the implications of profit sharing for equilibrium unemployment. Finally, we present concluding comments in section VI.

\section{Basic Framework}

We consider a firm operating in an environment characterized by uncertainty. In conformity with the efficiency wage hypothesis we assume that the output of the firm depends not only on the number of workers employed, but also on the effort supplied by each worker. By employing $L$ units of labour, each providing effort denoted by $a$, the stochastic revenues accruing to the firm are given by

$$
\theta R(a, L)
$$

where $\theta$ denotes a random revenue shock with a cumulative distribution function $F(\theta)$, and a density function $f(\theta)$, with the support $\left[\theta_{\text {min }}, \theta_{\max }\right] \subseteq R_{+}$. We assume that the production function $R(a, L)$ satisfies the following conventional properties: $R_{a}>0, R_{a a}<0, R_{L}>0, R_{L L}<0$ and $R_{a L}>0$.

The profit share, $\tau$, determines what fraction of the firm's profits is transferred to employed workers as part of the contract. We assume that profit share and base wage, $w$, are negotiated simultaneously between labour market organizations subject to labour demand and effort determination, i.e. the firm unilaterally determines the employment level and the employee the effort level once the conditions of the negotiations have been settled. In line with the tradition of efficiency-wage models, we assume that the representative union member decides on effort so as to maximize his objective function, which takes into account that effort provision causes disutility. As the trade union are formed by homogenous agents and as intra-organizational agency issues within the union are outside the scope of our analysis, the union is assumed to be able to enforce the effort provision by the representative union member so as to eliminate the potential free rider 
problems. ${ }^{1}$ At the stage of the base wage and profit share negotiations the negotiated partners hold rational expectations regarding how the outcome of the bargaining will impact on employment and effort.

We summarize the timing of the decisions made by the firm, the union and the representative union member in Figure 1. In the subsequent sections we turn to the analysis of the decisions taking place at the different stages of the firm- union interaction by solving the game in reverse order.

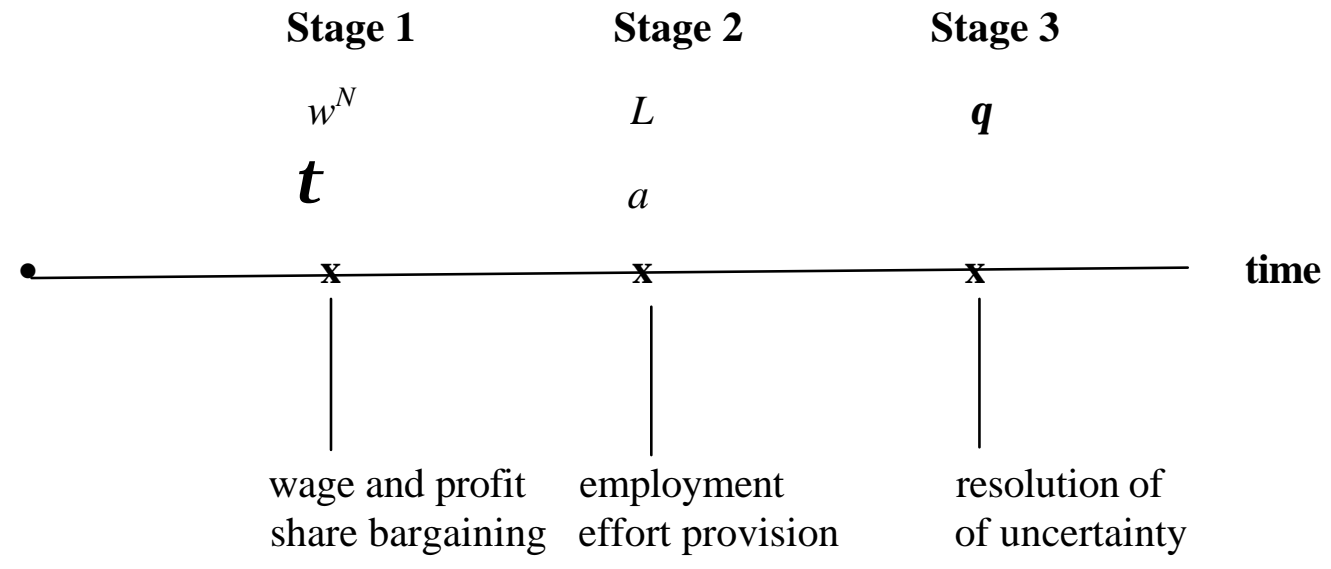

\section{Figure 1: Time sequence of decisions}

\section{Labour Demand and Equilibrium Effort}

We assume that the firm finances its activities by equity financing so that the effective cost of labour is $(1+r) w L$, where $w$ denotes the wage rate and $L$ is employment. From the firm's point of view r denotes the opportunity cost of capital. Under these circumstances the firm decides on employment $L$ so as to maximize the expected profits

$$
E \pi(a, L)=\int_{\theta_{\min }}^{\theta_{\max }}(\theta R(a, L)-w(1+r) L) f(\theta) d \theta
$$

\footnotetext{
${ }^{1}$ If we were to apply an alternative formulation where individual efforts were not directly observable and workers were heterogenous, group punishment or reward schemes would have to be used for enforcement (see e.g. Holmström (1982)).
} 
Conditional on the negotiated base wage and profit share contract the representative employed union member makes the effort decision in order to maximize the expected utility

(3) $E u(a, L)=w+\frac{\tau}{L} \int_{\theta \min }^{\theta_{\max }}(\theta R(a, L)-w(1+r) L) f(\theta) d \theta-g(a)$,

where the increasing and convex function $g(a)\left(g^{\prime}(a), g^{\prime \prime}(a)>0\right)$ is a monetary representation of the disutility of effort.

The optimal combination of employment and effort provision is determined by the system of first-order conditions

$$
\int_{\theta_{\min }}^{\theta_{\max }} \theta R_{L}(a, L) f(\theta) d \theta-w(1+r)=0
$$

and

$$
\frac{\tau}{L} \int_{\theta_{\min }}^{\theta_{\max }} \theta R_{a}(a, L) f(\theta) d \theta-g^{\prime}(a)=0 .
$$

According to equation (4) the firm chooses the employment level so as to equalize the expected marginal return from labour (the term $\theta R_{L}(a, L)$ ) to the effective wage cost (the term $w(1+r))$. Equation (5) characterizes the determination of effort by a representative employee so as to equalize the marginal benefit to the marginal disutility of effort.

In order to highlight the economic mechanisms involved as transparently as possible we make the following two assumptions regarding the functional forms of the production technology and the disutility of employee effort.

For the production technology we make

Assumption R: The technology is assumed to satisfy

$$
R(a, L)=\frac{(a L)^{\alpha}}{\alpha}
$$


The parameter $\alpha$ is restricted to $0<\alpha<1$. Thus specification $(\mathrm{R})$ describes a concave production function exhibiting decreasing returns to scale with effort and employment, separated as complementary production factors.

For the disutility of employee effort we make

Assumption G: The disutility of effort belongs to the class of iso-elastic functions $g(a)=\gamma a^{1 / \gamma}$ with $0<\gamma<1$.

This lies in conformity with the earlier discussion according to which the disutility of effort can be captured through an increasing and convex relationship.

Under assumptions $\mathrm{R}$ and $\mathrm{G}$ the equilibrium condition (4) with respect to the employment decision can be simplified to yield $a^{\alpha} L^{\alpha-1} \bar{\theta}=w(1+r)$, where $\bar{\theta}$ denotes the expected value of revenue shock. This can be written as follows

$$
L^{*}=\overline{\theta^{\eta}}[w(1+r)]^{-\eta} a^{\eta-1},
$$

where $\eta=1 /(1-\alpha)$ denotes the direct wage elasticity of labour demand. According to (6) labour demand depends negatively on the effective labour cost and positively on the effort of employees.

Analogously, under the assumptions made we can rewrite (5) according to $\tau(a L)^{\alpha-1} \bar{\theta}=a^{\frac{1}{\gamma}-1}$. Thus, the optimal effort is found to be given by

$$
a^{*}=[\tau w(1+r)]^{\gamma}
$$

We can now summarize our characterization of the optimal combination of employment and effort provision in 
Proposition 1 Labour demand depends negatively on the effective labour cost and positively on the effort of employees, while effort by employees depends positively on the profit share, the base wage as well as the cost of capital.

Equation (6) suggests that labour demand does not directly depend on profit sharing, which lies in conformity with empirical evidence (see e.g. Wadwani and Wall (1990)) and Cahuc and Dormont (1997)). Instead profit sharing enhances productivity by stimulating effort provision and through that mechanism profit sharing might possibly promote employment. The effective wage cost, $w(1+r)$, impacts negatively on labour demand and in the presence of profit sharing this increases the returns of effort provision. From (7) we can conclude that the optimal effort provision depends on profit sharing in a way, which reminds of the principalagent literature. These aspects have not previously been explored in the literature concerning union-firm wage bargaining.

Some aspects of the interactions between wage bargaining and efficiency wage considerations have previously been analyzed in Lindbeck and Snower (1991), Sanfey (1993), Summers (1988) and Garino and Martin (2000). In contrast to our analysis, in these papers the effort function is assumed ad hoc and it not derived from optimal behaviour. In Hendricks and Kahn (1991) the effort function is derived from optimal behaviour, but they do not explore the implications for equilibrium unemployment, which is our focus. Alterburg and Straub (1998) incorporate the efficiency wage considerations derived from optimal behaviour into an extended shirking model of the Shapiro-Stiglitz (1984) type with decentralized union bargaining. In such a context they study the relationship between aggregate labour market equilibrium and the benefit-replacement ratio. Like us they abstract from potential free-rider problems associated with effort determination, but they do not explore the employment implications of profit sharing. Bulkley and Myles (1996) have also studied the interaction between union power and shirking, but they confine attention to a partial equilibrium analysis. 


\section{Base Wage and Profit Share Negotiation}

We now turn to analyze the base wage and the profit share negotiations. We apply the Nash bargaining solution within the context of the 'right-to-manage' approach according to which employment is unilaterally determined by the firm, whereas effort is provided subject to the discretion of employees.

We denote the relative bargaining power of the union by $\beta$, and that of the firm by $(1-\beta)$. In line with (3) the objective function of the trade union can be written as

$$
E \hat{U}=L\left[w+\frac{\tau}{L} E \pi\right]+(N-L) b-L g(a),
$$

where the first term captures the benefits from employment to employed workers, the second term the benefits for unemployed union members and the last term denotes the disutility of effort for employed union members. We assume that the threat points of the union and the firm are $E U^{o}=N b$ and $E \pi^{o}=0$, respectively. Thus, the difference $E U=E U\left(a^{*}, L^{*}\right)=E \hat{U}-E U^{o}$ denotes the expected rent of the union relative to the threat point. At the stage of bargaining the expected profits and the expected rent of the union are evaluated at the equilibrium combination of effort and employment.

Applying the traditional Nash bargaining solution the negotiating parties decide on $w$ and $\tau$ in order to maximize

$$
\Omega=[E U]^{\beta}[(1-\tau) E \pi]^{1-\beta}
$$

subject to the labour demand (6) and the effort determination (7). In the Nash maximand

(8) $E \pi=E \pi\left(a^{*}, L^{*}\right)$ denotes the expected profit of the firm adjusted with the factor $(1-\tau)$ in order to take the impact of profit sharing into account.

In anticipation of the equilibrium with respect to effort provision and employment the expected profit of the firm is given by 


$$
E \pi=\frac{1}{\eta-1} w(1+r) L^{*}
$$

The calculation of the union's expected rent captures the idea that all the $\mathrm{N}$ workers have incentives to seek employment. Those union members who are left unemployed due to the limitations of the firm's production enjoy the outside option $b$. Thus the rent of the union, EU, is calculated to be

$$
E U=E U\left(a^{*}, L^{*}\right)=L^{*}\left[w-b+\frac{\tau}{L} E \pi\left(a^{*}, L^{*}\right)-g\left(a^{*}\right)\right] .
$$

The Nash bargaining solution has to satisfy the following first-order conditions

$$
\begin{aligned}
& \beta \frac{E U_{w}}{E U}+(1-\beta) \frac{E \pi_{w}}{E \pi}=0 \\
& \beta \frac{E U_{\tau}}{E U}+(1-\beta) \frac{E \pi_{\tau}}{E \pi}-\frac{1-\beta}{1-\tau}=0,
\end{aligned}
$$

where the subscripts $w$ and $\tau$ denote the partial derivatives with respect to the wage rate and the profit share, respectively. ${ }^{2}$ According to equations (11a) and (11b) the Nash bargaining wage rate and profit share are affected by the relative bargaining powers as well as by the relative effects of the wage rate and profit share on the objective functions of the negotiating agents. We find that the Nash bargaining solution, $w^{N}$, can be expressed through the implicit representation

$$
w^{N}=\frac{1+\frac{\beta}{\eta^{*}-1}}{1+\frac{\tau(1+r)}{\eta-1}} b+\frac{1}{1+\frac{\tau(1+r)}{\eta-1}} g\left(a^{*}\right)
$$

where $\eta^{*}=-\frac{w L_{w}^{*}}{L^{*}}=\eta-(\eta-1) \gamma$ denotes the total wage elasticity of labour demand, which incorporates both the direct negative employment effect of an increased wage and the indirect positive effect whereby by a wage increase stimulates effort provision.

In general, and unlike the earlier literature, (12) captures the idea that profit sharing has two opposite effects on the negotiated base wage. On the one hand, it tends to 
induce wage moderation as part of the compensation is shifted to the performance-related profit share. On the other hand, the effort-enhancing effects of profit sharing will also increase the costs of effort provision (the term $g\left(a^{*}\right)$ ) and thereby increase the "individual rationality" constraint of each union member, which will have a positive effect on the wage rate. By substituting (7) into (12) the Nash bargaining solution can be expressed in the explicit form according to

$$
w^{N}=\frac{1+\frac{\beta}{\eta^{*}-1}}{1+\tau(1+r)\left[\frac{1}{\eta-1}-\gamma\right]} b
$$

For the details of the calculations leading to (13) we refer to Appendix A. We can infer from (13) that the negotiated wage rate is proportional to the outside option $b$, increasing in the bargaining power of the union, and decreasing as a function of the total wage elasticity of labour demand. These effects coincide with those of conventional wage bargaining models except for the generalization that the total elasticity of labour demand incorporates an efficiency wage aspect. This effect will increase the base wage through the added disutility of effort. Under the plausible assumption that the wage-moderating effect dominates relative to the cost of effort provision, i.e. if $(\eta-1) \gamma<1$, we can now summarize our analysis in

Proposition 2: The Nash bargaining solution for the negotiated base wage is proportional to the outside option available to the union, increasing in the bargaining power of the union, and decreasing in the total wage elasticity of labour demand. Furthermore, profit sharing will moderate the negotiated base wage if $(\eta-1) \gamma<1$.

The negotiated base wage (13) represents a generalization along several dimensions relative to the traditional Nash bargaining solution. Our analysis with the Nash

\footnotetext{
2 We assume that the sufficient second-order conditions for the Nash bargaining solution (i) $\Omega_{w w}, \Omega_{\tau \tau}<0$ and (ii) $\Omega_{w w} \Omega_{\tau \tau}-\Omega_{w \tau} \Omega_{\tau w}>0$ hold.
} 
bargaining solution (13) simultaneously includes efficiency wage considerations like in Altenburg and Straub (1999), Bulkley and Myles (1996), Lindbeck and Snower (1991) and Sanfey (1993) and the price of capital like in Koskela, Schöb and Sinn (1998). But these models do not include profit sharing as an incentive device. The effect of profit sharing on the wage rate is analyzed in Holmlund (1991), but his model does not incorporate the important effort aspect of profit sharing.

The generalized Nash bargaining solution (13) implies several interesting special cases enabling interesting comparisons to relative to the existing knowledge from the literature. We now turn to consider these special cases one by one.

Firstly, in the absence of efficiency wage considerations we can reformulate (13) according to

$$
w^{N}=\frac{1+\frac{\beta}{\eta-1}}{1+\tau(1+r)} b .
$$

Thus, in the absence of efficiency wage considerations the wage-moderating effect of profit sharing is stronger as it is not reduced through the increased cost of effort provision. In this case the total wage elasticity of labour demand is reduced to the conventional elasticity.

Secondly, if all the bargaining power lies with the union $(\beta=1)$, the Nash bargaining solution is simplified to the monopoly union solution

$$
w^{M}=\frac{\frac{\eta^{*}}{\eta^{*}-1}}{1+\tau(1+r)\left[\frac{1}{\eta-1}-\gamma\right]} b .
$$

In particular, (15) demonstrates explicitly how efficiency wage considerations and profit sharing impact on the optimal wage setting of a monopoly union. Profit sharing will reduce the base wage, while efficiency wage considerations will raise it. In the absence of efficiency wage considerations and profit sharing, (15) implies the well-known monopoly wage $\left.w^{M}\right|_{\gamma=0, \tau=0}=\frac{\eta}{\eta-1} \quad b$ 
Thirdly, if all the bargaining power lies with the firm $(\beta=0)$, the wage would be determined so as to maximize the expected profits. From (13) this case yields

$$
w^{C}=\frac{1}{1+\tau(1+r)\left[\frac{1}{\eta-1}-\gamma\right]} b .
$$

According to (16) introduction of profit sharing makes it possible to reduce the base wage of the workers even below the outside option.

In terms of profit sharing we can solve the equation defined by the first-order condition (11b) to yield the following implicit representation of the negotiated profit share

$$
\tau^{N}=\frac{(\eta-1) \gamma+\beta(1-X)}{1+(\eta-1) \gamma-\beta X}
$$

where $0<X=\frac{1}{1+\frac{A}{A-1} \tau(1+r)\left[\frac{1}{\eta-1}-\gamma\right]}<1$ with $A=\frac{1+\frac{\beta}{\eta^{*}-1}}{1+\tau(1+r)\left[\frac{1}{\eta-1}-\gamma\right]}$ denoting the mark-up whereby the negotiated base wage $w^{N}$ exceeds the outside option $b$. For the details of the calculations leading to (17) we refer to Appendix B. From (17) we can directly infer that the negotiated profit share is an increasing function of the union's bargaining power, i.e. $\frac{\partial \tau^{N}}{\partial \beta}>0$. In particular, by allocating the bargaining power completely to the firm or to the union we obtain the following two special cases:

$$
0<\left.\tau^{c}\right|_{\beta=0}=\frac{(\eta-1) \gamma}{1+(\eta-1) \gamma}<1 \text { and }\left.\tau^{M}\right|_{\beta=1}=1
$$


In its general implicit form (17) represents a polynomial equation of the third degree. In general, we can guarantee the existence of solutions to such equations, but an explicit characterization of the roots might often be very cumbersome.

We can now summarize our general analysis of the negotiated profit share by

Proposition 3: The Nash bargaining solution for the profit share, characterized in implicit form by (17), is increasing in the bargaining power of the union, and it also depends on the wage elasticity of labour demand, the elasticity of disutility of effort as well as on the cost of capital.

We can exemplify (17) for the case with $\eta=2$. In this case (17) is reduced to the following quadratic equation:

$$
\tau^{2}+\frac{\gamma+1-\beta-(1+r)(1-\gamma)(1+\beta)}{2(1+r)(1-\gamma)} \tau-\frac{\gamma}{2(1+r)(1-\gamma)}=0
$$

the explicit solution of which can be easily be characterized. For example, it can be verified that $\tau=1$ for the special case with $\beta=1$.

\section{Profit Sharing and Equilibrium Unemployment}

After having solved the sequence of decisions from a partial equilibrium perspective we now move on to explore the implications of profit sharing on equilibrium unemployment in a general equilibrium framework. Our goal is to characterize the equilibrium unemployment as a function of the institutional features of the labour market, in particular the labour market imperfections and the coverage of the unemployment benefit system in terms of the benefit-replacement ratio.

Until now our wage bargaining analysis has referred to a representative industry, say i. By (13), for each representative industry the generalized Nash bargaining solution has the form

$$
w_{i}^{N}=A_{i} b
$$


where the wage mark-up $A_{i}$ is defined by

$$
A_{i}=\frac{1+\frac{\beta}{\eta^{*}-1}}{1+\tau(1+r)\left[\frac{1}{\eta-1}-\gamma\right]} \text {. }
$$

For simplicity we focus on an economy with identical industries so that $A_{i}=A$.

In a general equilibrium context the term $b$ should be re-interpreted to be the relevant outside option. We specify the outside option as

$$
b=(1-u)\left(w^{N}+\frac{\tau}{L} E \pi\right)+u B,
$$

where $u$ denotes the unemployment rate, $B$ the unemployment benefit and $w^{N}$ is the negotiated wage rate in all the identical industries [for a standard justification we refer to, for example, Layard et. al. (1991), pp. 100-101]. The formulation (21) captures the idea that all the identical industries adopt profit sharing so that an unemployed worker faces the probability $(1-u)$ of being employed in another industry, which makes use of a similar compensation scheme. We further restrict ourselves to the case of a constant replacement ratio $q \equiv B / w^{N}$.

We now formulate the following intuition-based conjecture for the employment effects of profit sharing in a general equilibrium context. In light of the Nash bargaining solution(13), profit sharing will have a wage-moderating effect, thereby contributing to a reduction in the outside option (21), and thus stimulating employment. On the other hand, increased profit sharing will add a direct positive effect to the relevant outside option, which will run counter to the wage-moderating effect. Finally, the unemployment compensation will add to the relevant outside option. If the benefit replacement ratio, $q$, is sufficiently high, the wage moderating effect of profit sharing makes it more likely that the overall effect of profit sharing is employment-enhancing. Thus, from the form of the rele vant outside option in the general equilibrium context, we have reasons to conjecture 
that profit sharing could stimulate employment as long as the benefit replacement ratio is sufficiently high so as to make the wage-moderating effect of profit sharing dominate relative to its direct effect. Our formal analysis will, in fact, confirm this intuition.

Next we turn to the formal analysis. Combining (20), (22) and the assumption of a constant replacement ratio we find that the aggregate unemployment rate can be expressed according to

$$
u^{N}=\frac{1-\frac{1}{A}+\frac{\tau E \pi}{w^{N} L}}{1-q+\frac{\tau E \pi}{w^{N} L}}=\frac{1-\frac{1}{A}+\frac{(1+r)}{\eta-1}}{1-q+\frac{(1+r)}{\eta-1}}
$$

where, by (21), $A=\frac{1+\frac{\beta}{\eta^{*}-1}}{1+\tau(1+r)\left[\frac{1}{\eta-1}-\gamma\right]}$ denotes the wage mark-up induced by the labour market imperfections.

From (23) we can conclude that $\frac{\partial u^{N}}{\partial q}>0$ and $\frac{\partial u^{N}}{\partial A}>0$. Hence, a higher benefit-replacement ratio and a higher wage mark-up, which is a positive function of the trade union's bargaining power and a negative function of the total wage elasticity of labour demand, will increase equilibrium unemployment. Further, differentiating (23) with respect to $\tau$ we find that

$$
\frac{\partial u^{N}}{\partial \tau}=-\frac{(1+r) q}{\eta-1}+\frac{A_{\tau}}{A^{2}}+\frac{(1+r)}{A(\eta-1)}\left[1+\frac{\tau A_{\tau}}{A}\right]
$$

where $A_{\tau}<0$ and $1+\frac{\tau A_{\tau}}{A}=\frac{1}{1+\tau(1+r)\left[\frac{1}{\eta-1}-\gamma\right]}>0$. Substituting this together with the definitions of $\mathrm{A}$ and $\eta^{*}$ into (24) yie lds 


$$
\frac{\partial u^{N}}{\partial \tau}=\frac{(1+r)}{\eta-1}\left[-q+\frac{\gamma(\eta-1)}{1+\frac{\beta}{(\eta-1)(1-\gamma)}}\right] .
$$

From (25) we can conclude that the following relationship between profit sharing and equilibrium unemployment holds:

$$
\frac{\partial u^{N}}{\partial \tau}\left\{\begin{array}{l}
< \\
= \\
>
\end{array}\right\} 0 \text { if and only if } \quad q\left\{\begin{array}{l}
> \\
= \\
<
\end{array}\right\} g(\beta, \gamma, \eta) \equiv \frac{\gamma(\eta-1)}{1+\frac{\beta}{(\eta-1)(1-\gamma)}} .
$$

The function $g(\beta, \gamma, \eta)$, defined in (26), is strictly decreasing as a function of $\beta$, strictly increasing as a function of $\eta$ and strictly concave as a function of $\gamma$. Moreover, it satisfies the boundary conditions $g(\beta, 0, \eta)=0$ and $g(\beta, \gamma, \eta) \rightarrow 0$, as $\gamma \rightarrow 1$.

From (26) we can conclude that the impact of profit sharing on equilibrium unemployment is determined by the interplay between labour market institutions (captured by $\beta$ ), labour market policy (captured by the replacement atio q), market conditions (captured by $\eta$ ) as well as the disutility of effort (captured by $\gamma$ ).

We can summarize our analysis, which reached its culmination in (26), in

Proposition 4: Higher profit sharing will reduce equilibrium unemployment if the benefit replacement ratio exceeds the threshold level $g(\beta, \gamma, \eta)$, while the reverse happens if the benefit-replacement ratio is below this threshold. The threshold depends negatively on the bargaining power of the union and positively on the elasticity of labour demand, whereas the relationship between the threshold and the disutility of effort is nonmonotonic.

Broadly speaking, we can conclude from (26) that higher profit sharing will reduce equilibrium unemployment under circumstances with sufficiently generous labour market policies, i.e. when both the benefit-replacement ratio and the relative bargaining 
power of trade unions are high. These circumstances are precisely those where the demand for employment-promoting policies are particularly high. Conversely, our model predicts that profit sharing might work very poorly as an employment-stimulating instrument, or even be a destructive from the point of view of employment, with sufficiently small labour market imperfections.

In Figures 1 and 2 we illustrate the threshold $g(\beta, \gamma, \eta)$ as a function of the labour market institution (captured by $\beta$ ), the labour market policy (captured by the replacement ratio q), the elasticity of effort (captured by $\gamma$ ) and the wage elasticity of labour demand (captured by $\eta$ ). On the upper side of the curves profit sharing serves as an instrument, which reduces equilibrium unemployment, while on the lower side the reverse happens. In Figure 1 the threshold $g(\beta, \gamma, \eta)$ is drawn for three different values of $\gamma$ with a fixed value of $\eta$. In particular, Figure 1 illustrates that the threshold $g(\beta, \gamma, \eta)$ is non-monotonic as a function of $\gamma$ as these curves may intersect. In Figure 2 we illustrate the impact of $\eta$ on the threshold $g(\beta, \gamma, \eta)$ by drawing this threshold for three different values of $\eta$, while keeping the value of $\gamma$ fixed.

From the comparative statics properties of $g(\beta, \gamma, \eta)$ we can directly draw the conclusion that profit sharing is more likely to stimulate employment the higher is the bargaining power of the trade union or the higher is the replacement ratio. Furthermore, profit sharing will always promote employment as we approach the limit case of effort costs approaching zero. Conversely, profit sharing can never be employment-enhancing in the absence of an institution of unemployment compensation.

We can summarize the policy lesson to be drawn from Proposition 4 as follows. Profit sharing is an employment-enhancing instrument in environments with sufficiently 'rigid' labour market institutions in the sense of sufficiently high benefit replacement ratios and sufficiently strong bargaining power of the trade unions. Under these circumstances the employment-enhancing effect of profit sharing can be seen as a consequence of its wage-moderating effect. Profit sharing is more likely to stimulate employment the larger are the labour market imperfections in the sense of higher wage mark-ups. 
Our results, characterized in proposition 4, add new dimensions to the literature. We have shown that the impact of profit sharing on equilibrium unemployment depends on the relationship between the benefit replacement ratio and its critical value, which in turns depends on the mark-up factor, the wage elasticity of effort and the wage elasticity of labour demand. This critical value is a decreasing function of the labour market imperfections. Thus, increased labour market imperfections will increase the potential for profit sharing as employment-enhancing instrument. By emphasizing how the employment consequences of profit sharing depend on the interplay between labour market polices and labour market imperfections we add an important element to the policy-oriented literature. This literature (see, for example, Holmlund (1991) or Layard and Nickell (1990)) has referred to particular properties of the production technology, in particular the elasticity of substitution between labour and capital, as the decisive features for evaluations of the employment implications of profit sharing. In their models profit sharing would have no effect on equilibrium unemployment in the absence of efficiency wage considerations if the firms operate with a Cobb-Douglas technology.

\section{Conclusions}

This study has offered a unified framework for simultaneously analyzing the determination of employment, effort provided by employed union members, wages, and profit sharing under uncertainty generated by a stochastic revenue shock. We initially showed that employment depends negatively on the effective labour cost. The effective labour cost consists not only of the wage rate, but also the cost of capital. Further, the effort provision by union members was shown to depend positively not only on the usual efficiency wage considerations, but we also characterized the effort-enhancing effects of profit sharing.

Base wage and profit share determination was analyzed by applying a generalized Nash bargaining solution, which extended the wage bargaining literature by incorporating not only efficiency wage considerations in the presence of uncertainty, but also profit sharing. The negotiated profit share was demonstrated to increase with the relative bargaining power of the trade union. Further, profit sharing was proven to moderate the 
negotiated base wage if the induced effort-promoting effect does not cause extremely high disutility costs.

Our analysis culminated in a characterization of how the equilibrium unemployment implications of profit sharing depend on the interplay between labour market policy and labour market imperfections. We proved that profit sharing will reduce equilibrium unemployment under conditions with sufficiently generous coverage of the unemployment benefit system and sufficiently strong relative bargaining power or unions. Under such circumstances profit sharing will induce moderations of the base wages so as to boost aggregate employment.

Even though there is empirical evidence on the determinants of employment and wages, which lies in conformity with our findings (see e.g. Nickell (1997) or Nickell and Layard (1999)), it still remains an important task for future research to evaluate the interactions between compensation structure and employment much more systematically than what has been done thus far. In terms of equilibrium unemployment consequences from profit sharing our analysis has highlighted the significance of labour market policy in the form of the benefit-replacement ratio. Under circumstances with sufficiently generous unemployment benefit systems profit sharing was shown to stimulate employment. Furthermore, this was shown to be more likely the higher is relative bargaining power of unions and the lower is the wage elasticity of labour demand. It is an interesting and unexplored area for future research to empirically test these predictions. 


\section{Appendix A: Derivation of the Nash bargaining wage rate}

This appendix develops the expressions for the terms $\frac{E \pi_{w}}{E \pi}$ and $\frac{E U_{w}}{E U}$ in the first-order condition (11a) of the Nash bargaining. We start by looking at the profit response by the firm to a change in the wage rate. The optimal employment decision of the firm has to satisfy the first-order condition $E \pi_{L}=0 \Leftrightarrow(a L)^{\alpha-1}=\frac{w(1+r) \lambda}{a \eta}$. By taking account of this condition we find that $E \pi_{w}=(1+r) \frac{L}{w}\left[\frac{w \lambda}{\eta} \frac{w a_{w}}{a}-w\right]=(1+r) L[\gamma-1]<0$, where the elasticity of effort with respect to wage $\frac{w a_{w}^{*}}{a^{*}}=\gamma$ is constant by (7). Hence, in light of equation (9) we can conclude that

$$
\frac{E \pi_{w}}{E \pi}=\frac{1}{w}[\gamma-1][\eta-1]<0
$$

As for the trade union side we find by combination of (10) and (9) that the ratio $\frac{E U_{w}}{E U}$ can be expressed according to

$$
\frac{E U_{w}}{E U}=\frac{1}{w}\left[-\eta^{*}+\frac{w+\frac{\tau}{L} E \pi\left((\gamma-1)(\eta-1)+\eta^{*}\right)-g\left(a^{*}\right)}{w-b+\frac{\tau}{L} E \pi-g\left(a^{*}\right)}\right],
$$

where $\eta^{*}=-\frac{w L_{w}^{*}}{L^{*}}=\eta-(\eta-1) \gamma$ denotes the total wage elasticity of wage demand. Making use of the total wage elasticity of wage demand we can rewrite (A2) according to

$$
\frac{E U_{w}}{E U}=\frac{1}{w}\left[\frac{\left(\eta^{*}-1\right)\left[g\left(a^{*}\right)-w-\frac{\tau}{L} E \pi\right]+\eta^{*} b}{w-b+\frac{\tau}{L} E \pi-g\left(a^{*}\right)}\right] .
$$

Substituting (A1) and (A3) into equation (11a) of the text yields (12). 


\section{Appendix B: Derivation of the Nash bargaining profit share}

This appendix develops the expressions for the terms $\frac{E \pi_{\tau}}{E \pi}$ and $\frac{E U_{\tau}}{E U}$ in the first-order condition (11b) of the Nash bargaining for profit sharing and solves it to produce equation (17) of the text. We first find that $E \pi_{\tau}=E \pi \frac{L_{a} a_{\tau}}{L}$ so that by using the properties of labour demand (6) and effort (7) equations we end up with

$$
\frac{E \pi_{\tau}}{E \pi}=\frac{(\eta-1) \gamma}{\tau}
$$

Differentiating $\quad E U=L\left[w-b+\frac{\tau}{L} E \pi-g(a)\right]$ with respect to $\tau$ yields $\left.\left.E U_{\tau}=L\left[\frac{L-\tau L_{\tau}}{L^{2}} E \pi+\frac{\tau}{L} E \pi_{\tau}-g^{\prime}\right) a\right) a_{\tau}\right]+L_{\tau}\left[w-b+\frac{\tau}{L} E \pi-g(a)\right], \quad$ which $\quad$ can $\quad$ be rewritten as $E U_{\tau}=\left\{[1-\gamma(\eta-1)]+\frac{\tau}{E \pi} E \pi_{\tau}\right\} E \pi-\frac{L g(a)}{\tau}+\frac{E U}{L} L_{\tau}$. Using the properties of labour demand and profit functions in terms of the profit share we get

$$
\frac{E U_{\tau}}{E U}=\frac{(\eta-1) \gamma}{\tau}+\frac{E \pi}{E U}-\frac{g(a)}{\tau\left[w-b+\frac{\tau}{L} E \pi-g(a)\right]}
$$

Now we can re-express the first-order condition (11b) as

$$
\frac{(\eta-1) \gamma}{\tau}+\frac{\beta}{\tau}\left[\frac{E U-L(w-b)}{E U}\right]-\frac{(1-\beta)}{(1-\tau)}=0
$$

After some manipulation we end up with

(B4) $\tau^{N}=\frac{(\eta-1) \gamma+\beta(1-X)}{1+(\eta-1) \gamma-\beta X}$,

where $0<X=\frac{1}{1+\frac{A}{A-1} \tau(1+r)\left[\frac{1}{\eta-1}-\gamma\right]}<1$ with $A=\frac{1+\frac{\beta}{\eta^{*}-1}}{1+\tau(1+r)\left[\frac{1}{\eta-1}-\gamma\right]}$ describing the negotiated mark-up between the base wage $w^{N}$ and the outside option $\mathrm{b}$. 


\section{References:}

Altenburg, L., Straub, M. (1998): Efficiency Wages, Trade Unions, and Employment, Oxford Economic Papers, 50, 726-746.

Bulkley, G., Myles, G.D. (1996): Trade Unions, Efficiency Wages and Shirking, Oxford Economic Papers, 48, 75-88.

Cahuc, P., Dormont, B. (1997): Profit Sharing: Does It Increase Productivity and Employment? A Theoretical Model and Empirical Evidence on French Micro Data, Labour Economics, 4, 293-319.

Garino, G., Martin, C. (2000): Efficiency Wages and Union-Firm Bargaining, Economics Letters, 69, 181-185.

Hendricks, W.E., Kahn, L.M. (1991): Efficiency Wages, Monopoly Unions and Efficient Bargaining, Economic Journal, 101, 1149-1162.

Holmlund, B. (1991): Profit Sharing, Wage Bargaining, and Unemployment, Economic Inquiry, 28, 257-268.

Holmström, B. (1982): Moral Hazard in Teams, Bell Journal of Economics, 13, 324-340.

Jerger, J., Michaelis, J. (1999): Profit Sharing, Capital Formation and the NAIRU, Scandinavian Journal of Economics, 101, 257-275.

Koskela, E., Schöb, R. Sinn, H.-W. (1998): Pollution, Factor Taxation and Unemployment, International Tax and Public Finance, 5, 379-393.

Koskela, E., Stenbacka, R. (2003): Profit Sharing, Credit Market Imperfections and Equilibrium Unemployment, mimeo, February.

Layard, R., Nickell, S.(1990): Is Unemployment Lower if Unions Bargain over Employment, Quarterly Journal of Economics, 105, 773-787.

Layard, R., Nickell, S., Jackman, R. (1991): Unemployment: Macroeconomic Performance and the Labour Market, Oxford University Press.

Lindbeck, A., Snower, D.J. (1991): Interactions between the Efficiency Wage and Insider-Outsider Theories, Economics Letters, 37, 193-196.

Nickell, S. (1997): Unemployment and Labor Market Rigidities: Europe versus North America, Journal of Economic Perspectives, 11, 55-74.

Nickell, S., Layard, R. (1999): Labour Market Institutions and Economic performance, in Ashenfleter, O., Card, D. (eds): Handbook of Labor Economics, Vol. 3, 3029-3084. 
Nickell, S., Wadhwani, S. (1991): Employment Determination in British Industry: Investigations Using Micro-Data, Review of Economic Studies, 58, 955-969.

OECD Employment Outlook (1995): Chapter 4, Profit Sharing in OECD Countries.

Pendleton, A., Poutsma, E., van Ommeren, J., Brewster, C. (2001): Employee Share Ownership and Profit Sharing in the European Union, Office for Official Publications of the European Commission, Luxembourg.

Sanfey, P.J. (1993): On the Interaction between Efficiency Wages and Union-Firm Bargaining Models, Economics Letters, 41, 319-324.

Shapiro, C. , Stiglitz, J.E. (1984): Equilibrium Unemployment as a Worker Discipline Device, American Economic Review, 74, 433-444.

Summers, L. H. (1988): Relative Wages, Efficiency Wages, and Keynesian Unemployment, American Economic Review, Papers and Proceedings, May, 78(2), 383388.

Wadhwani, S., Wall, M. (1990): The Effects of Profit Sharing on Employment, Wages, Stock Returns and Productivity: Evidence from U.K. Micro Data, Economic Journal, 100, 1-17.

Weitzman, M. (1984): The Share Economy: Conquering Stagflation, Cambridge MA, Harvard University Press.

Weitzman, M. (1985): The Simple Macroeconomics of Profit Sharing, American Economic Review, 75(5), p37-953.

Weitzman, M. (1987): Steady State Unemployment under Profit Sharing, Economic Journal, 97, 86-105. 


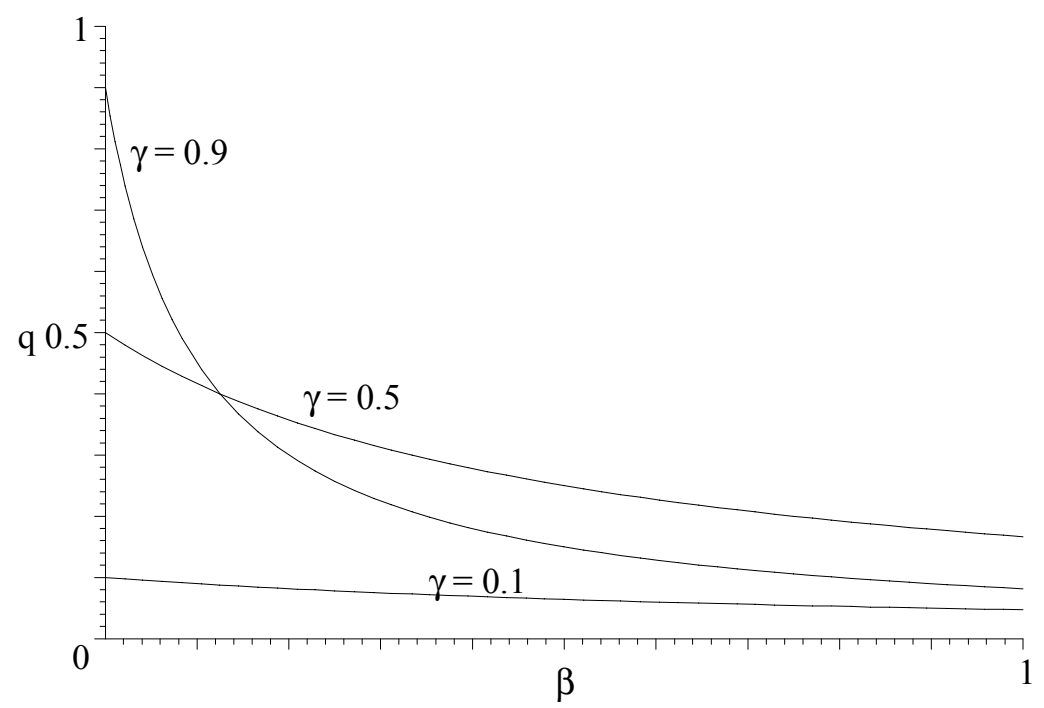

Fig 2. Illustration of the threshold $q(\beta, \gamma, \eta)$ for various values of $\gamma$.

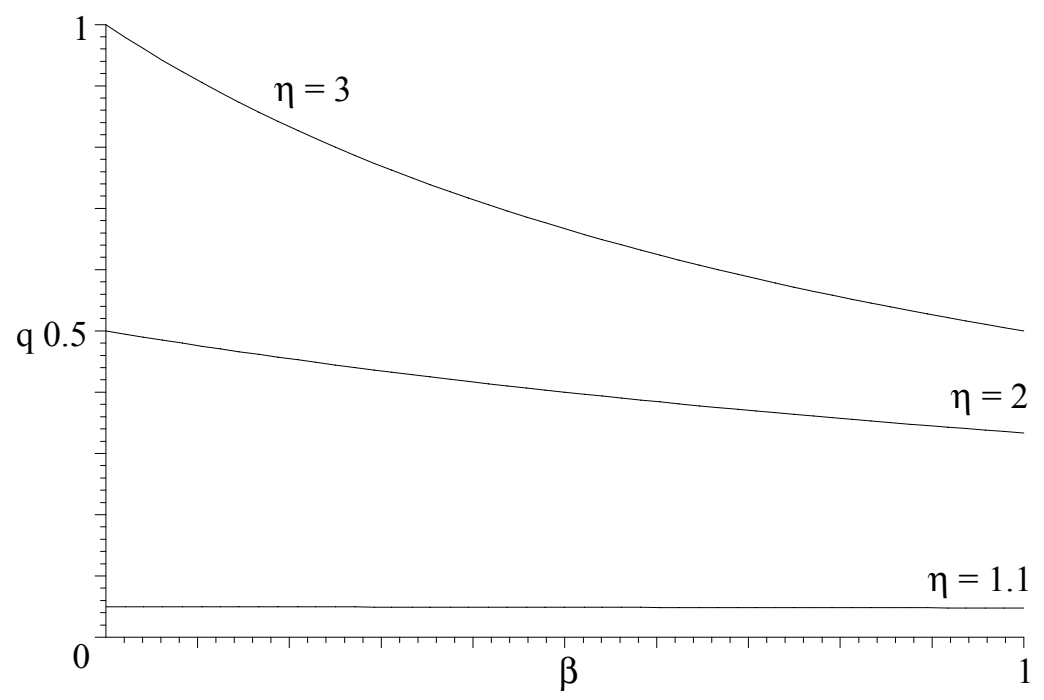

Fig 3. Illustration of the threshold $q(\beta, \gamma, \eta)$ for various values of $\eta$. 


\section{IZA Discussion Papers}

\begin{tabular}{|c|c|c|c|c|}
\hline No. & Author(s) & Title & Area & Date \\
\hline 826 & $\begin{array}{l}\text { K. T. Hansen } \\
\text { J. J. Heckman } \\
\text { K. J. Mullen }\end{array}$ & $\begin{array}{l}\text { The Effect of Schooling and Ability on } \\
\text { Achievement Test Scores }\end{array}$ & 6 & $07 / 03$ \\
\hline 827 & $\begin{array}{l}\text { H. Buddelmeyer } \\
\text { E. Skoufias }\end{array}$ & $\begin{array}{l}\text { An Evaluation of the Performance of Regression } \\
\text { Discontinuity Design on PROGRESA }\end{array}$ & 6 & $07 / 03$ \\
\hline 828 & $\begin{array}{l}\text { D. Checchi } \\
\text { T. Jappelli }\end{array}$ & School Choice and Quality & 3 & $07 / 03$ \\
\hline 829 & $\begin{array}{l}\text { J. J. Heckman } \\
\text { X. Li }\end{array}$ & $\begin{array}{l}\text { Selection Bias, Comparative Advantage and } \\
\text { Heterogeneous Returns to Education: Evidence } \\
\text { from China in } 2000\end{array}$ & 6 & $07 / 03$ \\
\hline 830 & T. J. Hatton & $\begin{array}{l}\text { Emigration from the UK, } 1870-1913 \text { and } 1950- \\
1998\end{array}$ & 1 & $07 / 03$ \\
\hline 831 & $\begin{array}{l}\text { J. H. Abbring } \\
\text { G. J. van den Berg }\end{array}$ & $\begin{array}{l}\text { Analyzing the Effect of Dynamically Assigned } \\
\text { Treatments Using Duration Models, Binary } \\
\text { Treatment Models, and Panel Data Models }\end{array}$ & 6 & $07 / 03$ \\
\hline 832 & P.-C. Michaud & Joint Labour Supply Dynamics of Older Couples & 3 & $07 / 03$ \\
\hline 833 & H. Gersbach & $\begin{array}{l}\text { Structural Reforms and the Macroeconomy: The } \\
\text { Role of General Equilibrium Effects }\end{array}$ & 2 & $07 / 03$ \\
\hline 834 & $\begin{array}{l}\text { T. Boeri } \\
\text { J. I. Conde-Ruiz } \\
\text { V. Galasso }\end{array}$ & $\begin{array}{l}\text { Protecting Against Labour Market Risk: } \\
\text { Employment Protection or Unemployment } \\
\text { Benefits? }\end{array}$ & 3 & $07 / 03$ \\
\hline 835 & $\begin{array}{l}\text { G. Joseph } \\
\text { O. Pierrard } \\
\text { H. R. Sneessens }\end{array}$ & $\begin{array}{l}\text { Job Turnover, Unemployment and Labor Market } \\
\text { Institutions }\end{array}$ & 3 & $07 / 03$ \\
\hline 836 & M.-S. Yun & $\begin{array}{l}\text { A Simple Solution to the Identification Problem } \\
\text { in Detailed Wage Decompositions }\end{array}$ & 3 & $07 / 03$ \\
\hline 837 & W. Schnedler & $\begin{array}{l}\text { What You Always Wanted to Know About } \\
\text { Censoring But Never Dared to Ask - Parameter } \\
\text { Estimation for Censored Random Vectors }\end{array}$ & 6 & $07 / 03$ \\
\hline 838 & $\begin{array}{l}\text { S. Girma } \\
\text { H. Görg } \\
\text { E. Strobl }\end{array}$ & $\begin{array}{l}\text { Government Grants, Plant Survival and } \\
\text { Employment Growth: A Micro-Econometric } \\
\text { Analysis }\end{array}$ & 6 & $07 / 03$ \\
\hline 839 & $\begin{array}{l}\text { A. Bassanini } \\
\text { G. Brunello }\end{array}$ & $\begin{array}{l}\text { Is Training More Frequent When Wage } \\
\text { Compression Is Higher? Evidence from the } \\
\text { European Community Household Panel }\end{array}$ & 6 & $08 / 03$ \\
\hline 840 & $\begin{array}{l}\text { E. Koskela } \\
\text { R. Stenbacka }\end{array}$ & $\begin{array}{l}\text { Equilibrium Unemployment Under Negotiated } \\
\text { Profit Sharing }\end{array}$ & 1 & $08 / 03$ \\
\hline
\end{tabular}

An updated list of IZA Discussion Papers is available on the center's homepage www.iza.org. 